\title{
Hereditary Tyrosinemia Type I: Lack of Correlation between Clinical Findings and Amount of Immunoreactive Fumarylacetoacetase Protein
}

\author{
E. A. KVITTINGEN, H. ROOTWELT, T. van DAM, H. VAN FAASSEN, AND R. BERGER \\ Institute of Clinical Biochemistry, Rikshospitalet, Oslo, Norway [E.A.K., H.R.]; Wilhelmina Kinderziekenhuis, \\ Utrecht, The Netherlands [T.v.D., R.B.]; and Department of Pediatrics, University of Groningen, \\ The Netherlands [H.v.F.]
}

\begin{abstract}
Immunoblot analyses with bovine fumarylacetoacetase antibodies have been performed in fibroblast extracts from 28 patients with hereditary tyrosinemia of various clinical phenotypes, in one healthy individual homozygous for a "pseudodeficiency" gene for fumarylacetoacetase, and in three tyrosinemia families in which one or both parents are compound heterozygotes for the tyrosinemia and pseudodeficiency genes. Liver extracts from two chronic patients were also investigated. None of the patients with the acute type of tyrosinemia had detectable immunoreactive protein in fibroblast extracts. Only two of seven patients with typical chronic tyrosinemia had definite immunoreactivity in fibroblasts. In liver tissue, one of the patients had cross-reactive material and the other had no immunoreactivity. Four of 13 patients with intermediate clinical findings showed immunoreactivity in fibroblasts. There was no relationship between severity of symptoms and amount of cross-reactive material in this group. The pseudodeficiency gene product gave almost no detectable immunoreactivity in fibroblasts. The results indicate that chronic tyrosinemia may be due to at least two protein variants, and immunoblotting does not classify tyrosinemia patients according to clinical findings. (Pediatr Res 31: 4346, 1992)
\end{abstract}

\section{Abbreviations}

FAH, fumarylacetoacetase

Hereditary tyrosinemia type I (McKusick 27670) is an inborn error of metabolism due to deficiency of FAH (EC 3.7.1.2), the last enzyme in the degradation of tyrosine (1). The disorder is characterized by renal tubular dysfunction with secondary hypophosphatemic rickets, and progressive liver damage. Hepatocellular carcinoma is frequently encountered (2). There is a considerable heterogeneity in the clinical picture, and the disorder is referred to as acute or chronic. In the acute form, the patients become severely ill during the first months of life and may die of liver failure in infancy. In the chronic form, symptoms appear later and are usually dominated by rickets until the liver disease becomes life-threatening because of advanced cirrhosis or development of hepatocellular carcinoma.

Recently, immunoblot analyses have shown that patients with

Received January 31, 1991; accepted July 11, 1991.

Correspondence: Dr. E. A. Kvittengen, Institute of Clinical Biochemistry, Rikshospitalet, 0027 Oslo 1, Norway. the acute form of tyrosinemia lack immunoreactive FAH protein, whereas patients with the chronic form have varying amounts of cross-reactive material $(1,3-6)$. In these reports, very few patients with chronic tyrosinemia were investigated. To decide if there is a consistent difference between acute and chronic tyrosinemia patients with regard to amount of immunoreactive FAH protein, we have performed Western blotting in fibroblast extracts from 28 patients with varying clinical pictures. In two chronic patients, immunoblotting was performed also in liver tissue.

Low FAH activity may be caused by a "pseudodeficiency" gene $(1,7)$. Healthy individuals who are homozygotes for the pseudodeficiency gene or compound heterozygous for pseudodeficiency and tyrosinemia have enzyme activity in fibroblasts nearly as low as that in tyrosinemia patients. If one or both parents in a tyrosinemia family have a compound heterozygous genotype, prenatal diagnosis by enzyme assay is not feasible because a low enzyme activity is not conclusive for tyrosinemia (8). If, in such families, the pseudodeficiency gene product gave immunoreactivity but the tyrosinemia gene product did not, immunoblotting could be of help in prenatal diagnosis. To decide this, fibroblast extracts from an individual presumably homozygous for the pseudodeficiency gene and from three tyrosinemia families with complex genotypes were investigated for immunoreactive FAH protein.

Our results show that few tyrosinemia patients, even among those with the chronic type, have immunoreactive FAH protein. The pseudodeficiency gene product did not give significant immunoreactivity in fibroblast extracts.

\section{MATERIALS AND METHODS}

Patient/person material. The subjects were 28 patients with hereditary tyrosinemia type I, three parent couples in which one or both parents were compound heterozygous for the tyrosinemia and pseudodeficiency genes, and one healthy adult individual presumably homozygous for the pseudodeficiency gene (7). In all 35 individuals, immunoblotting was performed in fibroblast extracts. In two tyrosinemia patients, liver tissue was also investigated. The diagnosis of tyrosinemia was in all patients established by demonstration of elevated excretion of succinylacetone in urine and by deficiency of FAH activity in fibroblasts and in liver tissue when available. When defining the groups for this investigation, we accepted as acute and chronic patients only those in whom the age of presentation, severity of symptoms, and time of survival were as dissimilar as possible. Most patients did not fit into these extreme groups and were sorted into an "intermediate" group. Descriptions of the patient groups are 
given below. All controls were Caucasians of Norwegian or Dutch origin.

Acute form of tyrosinemia. This group consisted of eight patients of mixed ethnic origin. All patients had severe symptoms of liver disease before the age of $4 \mathrm{mo}$. Seven died within $1 \mathrm{y}$ of age, and one had a liver transplant at 12 mo of age.

Chronic form of tyrosinemia. This group consisted of seven patients. Five were Norwegian, one was British, and the last was Turkish. The patients had no symptoms in early childhood, and the diagnosis of all patients was established after the age of $4 \mathrm{y}$. All except one Norwegian patient presented with rickets, and all the patients survived in good clinical condition to at least $8 \mathrm{y}$ of age. Treatment was with a low phenylalanine/tyrosine diet and/ or vitamin D supplementation, except for one patient who received no treatment. The two patients from whom liver tissue was available both presented at the age of $6 \mathrm{y}$ with rickets and had liver transplants after the age of $20 \mathrm{y}$. Clinical details on three of the Norwegian patients have been reported previously $(9-11)$.

"Intermediate" group. This group consisted of 10 patients of Scandinavian or Turkish origin. All presented within 12 mo of age. Generally, symptoms were moderate in infancy, but one patient had rather severe symptoms of liver disease at the age of 7 wk. All survived to at least 2 y of age; one was 18 y old at the time of the investigation. Brief individual case histories are given in Table 1.

Pseudodeficiency and tyrosinemia. A 41-y-old healthy female presumed to be homozygous for the pseudodeficiency gene (7) and three tyrosinemia families with complex genotypes were investigated for FAH immunoreactivity in fibroblasts. Family 1, in which the father was compound heterozygous for tyrosinemia and pseudodeficiency, has been reported previously (8). The child with tyrosinemia in this family presented at $12 \mathrm{mo}$ of age with abdominal distension, hepatomegaly, jaundice (slight), abnormal liver tests, and rickets. With dietary treatment from 1 y of age, the rickets healed but the liver dysfunction persisted. The patient died at 4 y of age from hepatocellular carcinoma. In family 2 , the father was compound heterozygous for tyrosinemia and pseudodeficiency. The affected daughter had renal tubular defects and prolonged clotting time at the age of 3 mo. At 17 mo of age, when the diagnosis was settled, she had rickets and slightly pathologic liver tests. A liver biopsy showed cirrhosis. The rickets healed on dietary treatment, and at $2.5 \mathrm{y}$ of age she was in good general condition with normal liver tests. In family 3 , both parents, who are Pakistani and are double first cousins, had a compound heterozygous genotype for tyrosinemia and pseudodeficiency. Their affected child was diagnosed on the neonatal screen for phenylketonuria when an increase of tyrosine was found. The baby had no clinical symptoms. A low tyrosine/ phenylalanine diet was started at age $7 \mathrm{wk}$. At age $2.5 \mathrm{y}$, he was clinically well with slightly abnormal liver tests and hepatomegaly. He also had hyperthrophic obstructive cardiomyopathy (12).

Preparation of fibroblast and liver extracts for immunoblotting. Fibroblasts were cultured in minimum essential medium (modified) (Flow Laboratories, Inc., Irvine, Scotland) supplemented with newborn calf serum (17\%) (National Institute of Health, Oslo, Norway), glutamine, and antibiotics and harvested with trypsin. The cell suspensions were washed three times in physiologic saline, and the cell pellets were frozen at $-70^{\circ} \mathrm{C}$. Liver tissue was obtained at liver transplantation, and the tissue was immediately frozen at $-70^{\circ} \mathrm{C}$. Liver tissue was homogenized in $0.025 \mathrm{~mol} / \mathrm{L} \mathrm{K}$-phosphate buffer, $\mathrm{pH}$ 7.2. Fibroblasts were homogenized in $300 \mu \mathrm{L}$ of the same buffer. The protein concentration was determined by the Lowry method (13), and aliquots containing $50 \mu \mathrm{g}$ of protein were treated with trichloroacetic acid, final concentration $10 \%$. After standing on ice, the precipitated protein was centrifuged $(10 \mathrm{~min}$ at $5000 \times \mathrm{g})$. The supernatant

Table 1. Tyrosinemia patients with clinical findings intermediate between those of typical acute and chronic groups*

\begin{tabular}{|c|c|c|c|c|c|}
\hline Patient & $\mathrm{CRM} \dagger$ & $\begin{array}{l}\text { Presenting age and symp- } \\
\text { toms/findings }\end{array}$ & Later symptoms/findings & Treatment & $\begin{array}{l}\text { Age at pres- } \\
\text { ent investiga- } \\
\text { tion }\end{array}$ \\
\hline A & - & $\begin{array}{l}9 \text { mo, resp. inf., sopor, tran- } \\
\text { sient increased blood pres- } \\
\text { sure }\end{array}$ & $\begin{array}{l}21 \text { mo, hepatomegaly, en- } \\
\text { larged kidneys (no rickets); } \\
\text { general condition good }\end{array}$ & None & $8 \mathrm{y}$ \\
\hline B & - & $12 \mathrm{mo}$, hepatomegaly, rickets & $\begin{array}{l}\text { Peripheral neuropathy and } \\
\text { pathologic liver tests during } \\
\text { minor inf. }\end{array}$ & $\begin{array}{l}\text { Diet from age } 1 \mathrm{y} \text {; liver } \\
\text { transplanted at age } 3 \mathrm{y}\end{array}$ & $7 y$ \\
\hline $\mathrm{C}$ & - & $\begin{array}{l}12 \text { mo, hepatomegaly, rick- } \\
\text { ets, s.c. hemorrhage }\end{array}$ & $\begin{array}{l}\text { Hepatomegaly, consistently } \\
\text { and highly elevated } \alpha \text {-feto- } \\
\text { protein }\end{array}$ & $\begin{array}{l}\text { Diet from age } 1 \mathrm{y} \text {; liver } \\
\text { transplanted at age } 3 \mathrm{y}\end{array}$ & Dead, age 4 y \\
\hline $\mathrm{D}$ & + & $\begin{array}{l}18 \text { mo, hepatosplenomegaly, } \\
\text { rickets }\end{array}$ & $\begin{array}{l}\text { Few symptoms, normal liver } \\
\text { tests }\end{array}$ & $\begin{array}{l}\text { Diet from age } 18 \text { mo, vit } \\
\text { D and phosphate }\end{array}$ & $3 y$ \\
\hline E & + & $\begin{array}{l}3 \text { mo, hepatomegaly, rickets, } \\
\text { abnormal liver tests }\end{array}$ & $\begin{array}{l}\text { Slightly abnormal liver tests, } \\
\text { abdominal distension, rick- } \\
\text { ets }\end{array}$ & $\begin{array}{l}\text { Diet from age } 10 \mathrm{mo} \text {, vit } \\
\mathrm{D} \text {, phosphate and di- } \\
\text { uretics }\end{array}$ & $2 y$ \\
\hline $\mathrm{F}$ & + & 1 mo, hepatomegaly & $\begin{array}{l}7 \text { wk, hepatomegaly, ascites, } \\
\text { depressed coagulation fac- } \\
\text { tors; } 3 \text { mo, rickets; later } \\
\text { general condition good }\end{array}$ & Diet from age $3 \mathrm{mo}$ & $5 y$ \\
\hline G & - & $<$ l mo, hypoglycemia & $\begin{array}{l}\text { Few clinical symptoms and } \\
\text { findings }\end{array}$ & Diet from neonatal period & $5 y$ \\
\hline $\mathrm{H}$ & - & 3 mo, craniotabes & $\begin{array}{l}8 \text { mo, hepatomegaly, retarded } \\
\text { growth, craniotabes; } 9 \text { y, } \\
\text { rickets; normal liver tests }\end{array}$ & $\begin{array}{l}\text { Diet from age } 2 y \text {, vit } D \\
\text { from age } 9 y\end{array}$ & $18 \mathrm{y}$ \\
\hline I & - & $12 \mathrm{mo}$, hepatomegaly, rickets & $\begin{array}{l}\text { Variable liver dysfunction; } 4 \\
\text { y, hepatocellular carcinoma }\end{array}$ & Diet from age $1 y$ & Dead, age 4 y \\
\hline $\mathrm{J}$ & - & 9 mo, hepatosplenomegaly & $\begin{array}{l}4 \mathrm{y} \text {, rickets, hepatomegaly; } \\
\text { normal liver tests }\end{array}$ & $\begin{array}{l}\text { Diet from } 4 \mathrm{y} \text {, vit D and } \\
\text { phosphate }\end{array}$ & $6 y$ \\
\hline
\end{tabular}

* Immunoblots of fibroblasts from the patients are shown in Figure 3. As indicated, patients D, E, and F have cross-reactive material present, whereas the others are negative.

$\dagger$ CRM, cross-reactive material. 
was removed, and the protein was dissolved in sample buffer (4) and neutralized with $2 \mathrm{M}$ Tris.

Assay of FAH. Assay of FAH in fibroblasts and liver tissue was performed as reported previously (14). Enzyme activity is expressed in units (U), $1 \mathrm{U}$ being the amount of enzyme hydrolyzing $1 \mu \mathrm{mol}$ of substrate (fumarylacetoacetate) per minute.

Electrophoresis and immunologic detection of FAH protein. Electrophoresis and immunologic detection of FAH protein were performed as described previously (4). Proteins were separated by discontinuous PAGE (3\% stacking gel, 10\% separating gel) and transferred to a nitrocellulose filter. After incubation with polyclonal antibodies to bovine $\mathrm{FAH}$, immune complexes were visualized with a second antibody (antirabbit IgG; Sigma Chemical Co., St. Louis, MO) conjugated with alkaline phosphatase.

\section{RESULTS}

The FAH activity in fibroblasts of all the tyrosinemia patients was less than $0.15 \mathrm{U} / \mathrm{g}$ protein (reference range 2.3-3.9). The pseudodeficiency homozygous individual had an activity of 0.3 $\mathrm{U} / \mathrm{g}$ protein, whereas the four individuals presumed to be compound heterozygous for tyrosinemia and pseudodeficiency all had activities of $0.2 \mathrm{U} / \mathrm{g}$ protein (mean value of at least four determinations) in fibroblasts. In liver tissue, the two tyrosinemia patients had FAH activities of less than $2 \mathrm{U} / \mathrm{g}$ protein (reference range 33-66).

None of the eight patients with acute tyrosinemia had demonstrable immunoreactive FAH protein in fibroblast extracts with $50 \mu \mathrm{g}$ of protein applied as shown in Figure 1. In two different controls, bands were visible even with $12.5 \mu \mathrm{g}$ of protein applied.

Among seven patients with chronic tyrosinemia, only two patients had clearly detectable bands of immunoreactive protein in fibroblasts comparable to that of the control, and two additional patients had trace amounts of immunoreactivity (Fig. 2).

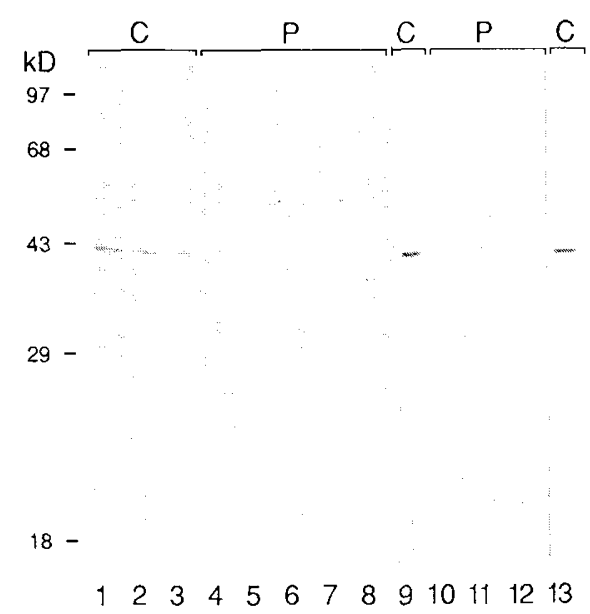

Fig. 1. Immunoblots of fibroblast extracts from eight patients $(P)$ with acute tyrosinemia (lanes $4-8$ and 10-12). Fifty mg of protein were applied. Lanes $1,2,3,9$, and 13 show controls $(C)$ with 50, 25, 12.5, 25, and $25 \mu \mathrm{g}$ of protein, respectively.

$\mathrm{C} \longrightarrow \mathrm{P}$

\section{3}

Fig. 2. Immunoblots of fibroblast extracts from seven patients $(P)$ with chronic tyrosinemia (lanes 4-10). Fifty $\mu \mathrm{g}$ of protein were applied. Lanes $1,2,3,11,12$, and 13 show control $(C)$ samples with $50,25,12.5$, 50,25 , and $12.5 \mu \mathrm{g}$ of protein, respectively.

$\stackrel{C}{A B C D E F G H I J}$

\section{6}

Fig. 3. Immunoblots of FAH protein in fibroblasts from 10 tyrosinemia patients $(P)$ with intermediate clinical symptoms (lanes 4-13; patients $A-J$ described in Table 1). Fifty $\mu \mathrm{g}$ of protein were applied. Lanes $1,2,3,14,15$, and 16 show controls $(C)$ with $50,25,12.5,50,25$, and $12.5 \mu \mathrm{g}$ of protein.

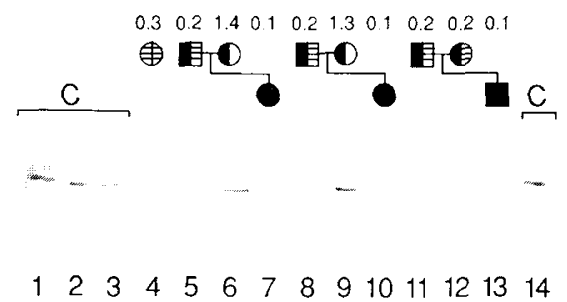

Fig. 4. Immunoblots of fibroblast extracts from an individual homozygous for the pseudodeficiency gene (lane 4 ) and from three tyrosinemia families in which one or both parents were compound heterozygous for the tyrosinemia and pseudodeficiency genes (lanes 5-13). Families 1, 2, and 3 from left to right (see text for individual description). Fifty $\mu \mathrm{g}$ of protein were applied. Controls $(C)$ are shown in lanes $1,2,3$, and 14 with $50,25,12.5$, and $50 \mu \mathrm{g}$ of protein, respectively. The numbers above the pedigrees refer to the fibroblast FAH activities ( $\mathrm{U} / \mathrm{g}$ protein). The reference range for $\mathrm{FAH}$ in fibroblasts was $2.3-3.9 \mathrm{U} / \mathrm{g}$ protein. $\mathbf{E}, \mathrm{T} / \mathrm{P} ; \boldsymbol{O}, \mathrm{T} / \mathrm{N} ; \boldsymbol{\bullet}$ and $\mathbf{\square}, \mathrm{T} / \mathrm{T}$, and $\oplus, \mathrm{P} / \mathrm{P}$, where $\mathrm{T}=$ tyrosinemia, $\mathrm{P}$ = pseudodeficiency, and $\mathrm{N}=$ normal.

In Figure 3, immunoblots of fibroblast extracts from patients in the intermediate group are shown. Three patients, D, E, and $\mathrm{F}$ (Table 1), had amounts of cross-reactive material comparable to that of a control, and seven were negative for cross-reactive material. One patient, $\mathrm{A}$, had a trace of immunoreactivity evident on the original blot.

Figure 4 shows immunoblots of fibroblasts from the individual presumed to be homozygous for the pseudodeficiency gene and from the three tyrosinemia families with complex genotypes. The pseudodeficiency homozygous individual had only traces of immunoreactive protein. In family 1 , the father, who is compound heterozygous for tyrosinemia and pseudodeficiency, had a slight amount of cross-reactive material, whereas the affected daughter was negative. In family 2 , both the affected child and the compound heterozygous father had some immunoreactive protein, indicating that the tyrosinemia gene product gave some immunoreactivity in this family. None of the members in family 3 , in which both parents are compound heterozygotes, had immunoreactive FAH protein. The two ordinary heterozygous mothers in families 1 and 2 had amounts of cross-reactive material comparable to that of the control.

Immunoblots of liver tissue extracts from two chronic patients are given in Figure 5. One patient had no immunoreactivity in liver tissue, and this patient had only a trace of cross-reactive material in fibroblast extract. The other patient had a clear band in liver tissue, but the amount of cross-reactive material was somewhat reduced compared with that of the control. This patient also had distinct immunoreactivity in fibroblasts.

\section{DISCUSSION}

Acute and chronic tyrosinemia refer to clinical findings, and no clear definition of these terms exists. Environmental factors, intercurrent infections, and the background genetic makeup of the patients are likely to influence the expression of the disorder 


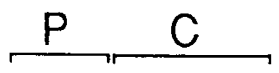

\section{5}

Fig. 5. Immunoblots of liver tissue extracts from two chronic patients $(P)$ (lanes $I$ and 2). Ten $\mu \mathrm{g}$ of protein were applied. Immunoblots of fibroblast extracts from these patients are shown in Figure 2, lanes 7 and 4 , respectively. A control $(C)$ with 10,5 , and $2.5 \mu \mathrm{g}$ of protein applied is shown in lanes 3-5.

and could easily make a chronic patient appear as an acute patient. Different mutations, however, may be part of the explanation for the phenotypic variation.

Biochemical distinction between chronic and acute tyrosinemia has been claimed on the basis of residual FAH enzyme activity; chronic patients having significant residual activity $(5$, 6 ). With our method of enzyme analysis, all patients in the present study had less than $5 \%$ of mean control enzyme activity in fibroblasts and liver tissue.

The finding that acute tyrosinemia patients lacked immunoreactive $\mathrm{FAH}$ protein and chronic patients had reduced amounts (1, 3-6) was a promising distinction between the two forms of tyrosinemia and indicated that the two types were indeed caused by different protein variants. Berger et al. (3) have further shown, by pulse label pulse-chase experiments, that the difference in immunoreactivity between one acute and one chronic patient was due to varying stability of the FAH protein. The acute patient had a very unstable protein, whereas the chronic patient had stability between that of the acute patient and normal controls. In a recent publication by Tanguay et al. (6), the results of the immunoblots indicated true absence of FAH protein in their patients with acute tyrosinemia.

Consistent with previous reports, we have found that patients with the acute type of tyrosinemia apparently lack immunoreactive FAH protein. Our results show, however, that there is variability in immunoreactive FAH protein among patients in the chronic group. Only two of seven chronic patients showed distinct bands of immunoreactivity in fibroblasts, and one chronic patient had no cross-reactive material in liver tissue. This indicates that there may exist at least two protein variants in the chronic group. Among the patients in the intermediate group, there was no consistent relationship between amount of cross-reactive material and severity of symptoms; patient $\mathrm{F}$ (Table 1), who had rather severe symptoms in the 1st year of life, had a definite band of immunoreactive FAH protein (Fig. 3 , lane 9), whereas patient $\mathrm{H}$, with mild symptoms, had no immunoreactivity (Fig. 3, lane 11).

The pseudodeficiency gene products did not give clear signals in our system. The individual who was homozygous for pseudodeficiency had approximately $10 \%$ of mean control FAH activity in fibroblasts, and the protein was detected as a trace, possibly indicating the sensitivity limit for the immunoblot system. This individual had no clinical symptoms and had clearly less immunoreactivity than several patients with tyrosinemia, demonstrating that the amount of cross-reactive material may not be correlated with clinical findings. In the three investigated tyrosinemia families with complex genotypes, immunoblotting would be of little help in prenatal diagnosis of tyrosinemia, inasmuch as the pseudodeficiency gene product gave no definite immunoreactivity in these families.

Liver transplantation is optional in the treatment of tyrosinemia, and a well-founded biochemical classification could be of some help in deciding the time for liver transplantation in patients with the less acute forms of the disorder. Immunoblotting does not appear to classify a tyrosinemia patient in consistence with the clinical picture. For a more valid classification, efforts must be made to identify the exact mutations causing the defective enzyme activity.

Acknowledgments. The authors thank the following for fibroblast cultures and clinical data on their patients: Dr. Byrd, Hannover (patient F); Dr. Christensen, Copenhagen (patient G); Dr. Elinder, Stockholm (patient H); Dr. Freycon, Saint-Etienne, and Mrs. Zabot, Lyon (pseudodeficiency family 2); Dr. Halvorsen, Oslo (patient B); Dr. Kelly and Mrs. Green, Birmingham (pseudodeficiency family 3); Dr. Leonard, London (pseudodeficiency family 1); Dr. Ozalp, Ankara (patients D, E, and J); and Dr. Søvik, Bergen (patients A and C).

\section{REFERENCES}

1. Goldsmith LA, Laberge C 1989 Tyrosinemia and related disorders. In: Scriver CR, Beaudet AL, Sly WS, Valle D (eds) The Metabolic Basis of Inherited Disease. McGraw-Hill, New York, pp 547-562

2. Weinberg AG, Mize CE, Worthen $H G 1976$ The occurrence of hepatoma in the chronic form of tyrosinemia. J Pediatr 88:434-438

3. Berger R, van Faassen H, Taanman JW, de Vries H, Agsteribbe A 1988 Different types of mutations in the chronic and acute forms of type I tyrosinemia. Pediatr Res 24:266(abstr)

4. Berger R, van Faassen H, Taanman JW, de Vries H, Agsteribbe A 1987 Type I tyrosinemia: lack of immunologically detectable fumarylacetoacetase enzyme protein in tissues and cell extracts. Pediatr Res 22:394-398

5. Tanguay RM, Laberge C, Lescault A, Valet JP, Duband JL, Quenneville Y 1984 Molecular basis of hereditary tyrosinemias: proof of the primary defect by Western blotting. In: Scott WA, Ahmad F, Black S, Schultz J, Whelan WJ (eds) Advances in Gene Technology: Human Genetic Disorders. Cambridge University Press, Cambridge, UK, pp 250-251

6. Tanguay RM, Valet JP, Lescault JL, Duband JL, Laberge C, Lettre F, Plante M 1990 Different molecular basis for fumarylacetoacetate hydrolase deficiency in the two forms of hereditary tyrosinemia (type I). Am J Hum Genet 47:308-316

7. Kvittingen EA, Leonard JV, Pettit BR, King GS 1985 Concentrations of succinylacetone after homogentisate and tyrosine loading in healthy individuals with low fumarylacetoacetase activity. Clin Chim Acta 152:271-279

8. Kvittingen EA, Steinmann B, Gitzelmann R, Leonard JV, Andria G, Børresen AL, Mossman J, Micara G, Lindblad B 1985 Prenatal diagnosis of hereditary tyrosinemia by determination of fumarylacetoacetase in cultured amniotic fluid cells. Pediatr Res 19:334-337

9. Kvittingen EA, Jellum E, Stokke O, Flatmark A, Bergan A, Sødal G, Halvorsen S, Schrumpf E, Gjone E 1986 Liver transplantation in a 23-year-old tyrosinaemia patient: effects of the renal tubular dysfunction. J Inherited Metab Dis 9:216-224

10. Søvik O, Kvittingen EA, Steen-Johnsen J, Halvorsen S 1990 Hereditary tyrosinemia of chronic course without renal tubular dysfunction. Acta Paediatr Scand 79:1063-1068

11. Kvittingen EA, Talseth T, Halvorsen S, Jakobs C, Hovig T, Flatmark A 1991 Renal failure in adult patients with hereditary tyrosinaemia type I.J Inherited Metab Dis 14:53-62

12. Edwards MA, Green A, Colli A, Rylance G 1987 Tyrosinaemia type I and hypertrophic obstructive cardiomyopathy. Lancet 1:1437

13. Lowry OH, Rosebrough NJ, Farr AL, Randall RJ 1951 Protein measurement with the folin phenol reagent. J Biol Chem 193:265-275

14. Kvittingen EA, Brodtkorb E 1986 The pre- and post-natal diagnosis of tyrosinemia type $I$ and the detection of the carrier state by assay of fumarylacetoacetase. Scand J Clin Lab Invest 46(suppl 184):35-40 